\title{
Using Problem Based Learning Based Online Learning to Improve Senior High School Students Problem Solving Skills
}

\author{
Rifda Indrawsari ${ }^{1, *}$, Rahmat Rahmat ${ }^{2}$ \\ 1,2 Universitas Pendidikan Indonesia, Bandung, Indonesia \\ ${ }^{*}$ Corresponding author.Email: rifdaindraswari@upi.edu
}

\begin{abstract}
This study focuses on the results of testing online-based problem learning model in senior high school students to improve students' problem solving skills in Civic education.. It is expected that from this study, students can think critically on the issues discussed in civics learning both through the process of expressing opinions in person and through class discussions to improve students' problem solving skills in civic education.
\end{abstract}

Keywords: Online Learning, Problem Based Learning, Senior High School, Student Problem Solving Skills.

\section{INTRODUCTION}

In the face of 21 st century education today emphasizes more on the ability of learners in solving problems creatively in the framework of lifelong learning or long-life learning with various conditions and challenges that exist.

Creativity has a big impact for education because in critical and creative thinking find to solutions (Beetlestone, 2011). Efforts are made to improve the problem-solving skills of learners in civic education subjects by improving the learning process, namely by applying the Problem Based Learning model.

This PBL model is expected to effectively toward the problem-solving skills of students in civic education subjects. This study was conducted to gather sufficient information related to the use of online-based problem learning models in high school students in an effort to improve students' problem solving skills.

\section{THEORETICAL REVIEW}

According to Hariyanto and Suyono, the learning model is the whole planning and procedures and steps of learning activities that include the choice of how the assessment will be carried out [1]. According to Sani, the learning model is a conceptual framework in the form of systematic procedure patterns developed based on theory and used in organizing the teaching and learning process to achieve learning objectives [2]. Shoimin said that problem based learning model is problem-based learning with teaching model that characterizes real problems as context for learners learning critical thinking and problem solving skills and gaining knowledge [3].

\section{METHOD}

The method used in this study is a literature study which was conducted by the collection of several previous studies to answer the use of problem-based learning models in improving the problem-solving skills of secondary school students.

\section{RESULT AND DISCUSSION}

This research focuses on improving students' solving skills by using online-based problem learning models. From several preliminary studies, there are some facts related to online learning models based on improving the problem skills of learners. Among other things; problem based learning with scientific thinking characteristics will train students to improve their thinking skills; each activity in the PBL learning series, is an effort to train students' skills in solving problems (Simamora, 2017) [4]. But in other studies experienced contradictory statements, namely: The implementation of problem based learning through lessons in the field of study is enough to improve students' problem solving skills, but we also found students who are still less active in group conversations and discussion classes (Narmaditya, 2018) [5].

The role of teachers becomes very important, it is expected to be able to transfer knowledge by forming questions evoking the ability to solve learners in order to 
think critically, especially on problems or social phenomenon.

It is assumed that students have the same abilities, then given stimulus in the hope that the response can improve the solving skills of learners. The problem based learning model is presented in some previous studies by measuring using post test and pre test.

\section{CONCLUSION}

Therefore, it can be concluded that Problem-Based Learning can improve critical thinking skills in students. The result of learning in the learning process, the improvement of thinking skills is demonstrated by the ability to solve problems and make conclusions through the thought process. By providing a particular problem, students will critically propose an idea for the problem by collecting some material from books and data from the internet, analyzing the information collected and proposing ways to resolve the issue.

\section{REFERENCES}

[1] Suyono, dkk. (2011). Belajar dan Pembelajaran.Bandung: Remaja Rosdakarya.

[2] Sani, Abdullah. (2013). Inovasi Pembelajaran. Jakarta: Bumi Aksara.

[3] Shoimin, Aris. (2014). 68 Model Pembelajaran Inovatif dalam Kurikulum 2013. Yogyakarta: ArRuzz Media.

[4] R. Simamora, "Improving Learning Activity and Students' Problem Solving Skill through Problem Based Learning (PBL) in Junior High School", International Journal of Sciences: Basic and Applied Research (IJSBAR). May 2017

[5] B. Narmaditia, "Does Problem-Based Learning Improve Critical Thinking Skills?", Cakrawala Pendidikan, Oktober 2018, Th. XXXVII, No. 3 